\title{
Gambaran Jumlah Trombosit Dan Kadar Hematokrit Pasien Demam Berdarah Dengue Di Rumah Sakit Islam Siti Rahmah Padang
}

\author{
Kafrawi, Vudhya Ulhaq ${ }^{1}$, Dewi, Nadia Purnama ${ }^{2}$, Adelin, Prima ${ }^{3}$ \\ ${ }^{1}$ Mahasiswa Fakultas Kedokteran Universitas Baiturrahmah, Padang, Indonesia \\ E-mail : vudhyaulhaq123@gmail.com \\ ${ }^{2}$ Bagian Anatomi Fakultas Kedokteran Universitas Baiturrahmah, Padang, Indonesia \\ ${ }^{3}$ Bagian Patologi Klinik Fakultas Kedokteran Universitas Baiturrahmah, Padang, Indonesia
}

\begin{abstract}
Abstrak
Latar Belakang: Demam Berdarah Dengue (DBD) adalah penyakit yang disebabkan oleh virus dengue. Dinas Kesehatan Sumatera Barat melaporkan bahwa kota Padang merupakan kota tertinggi angka kejadian demam berdarah dengue di Sumatera Barat. Diketahui bahwa jumlah trombosit serta kadar hematokrit merupakan indikator penting dalam menentukan terjadinya syok serta tingkat keparahan penyakitnya. Tujuan: untuk mengetahui gambaran jumlah trombosit serta kadar hematokrit merupakan indikator penting dalam menentukan terjadinya syok serta tingkat keparahan penyakitnya Metode: Jenis penelitian ini adalah penelitian deskriptif menggunakan rancangan cross sectional dengan pendekatan retrospektif, penelitian ini dilakukan di Rumah Sakit Islam Siti Rahmah Padang. Populasi dalam penelitian ini adalah seluruh data rekam medik pasien yang sudah didiagnosis demam berdarah dengue oleh dokter Spesialis Penyakit Dalam di Rumah Sakit Islam Siti Rahmah Padang periode 1 Januari-31 Desember 2017, yaitu sebanyak 162 orang dengan 62 sampel dengan teknik simple random sampling. Hasil: Analisa univariat disajikan dalam bentuk tabel distribusi frekuensi. Hasil penelitian diperoleh umur terbanyak adalah dewasa awal yaitu $69,4 \%$ dan jenis kelamin terbanyak adalah perempuan yaitu 58,1\%.Derajat klinis paling banyak adalah derajat 1 yaitu $58,1 \%$. Sebagian besar pasien memilik ijumlah trombosit $<100.000$ sel/mm3yaitu $64,5 \%$ dengan rata-rata jumlah trombosit 87.790 $\mathrm{sel} / \mathrm{mm}^{3}$.Sebagian besar kadar hematokrit normal yaitu $67,7 \%$ dengan rata-rata kadar hematokrit adalah 40,45\%. Berdasarkan derajat 1 sebagian besar dengan jumlah trombosit $<100.000 \mathrm{sel} / \mathrm{mm}^{3}$ yaitu $55,6 \%$, pada derajat 2 sebagian besar dengan jumlah trombosit $<100.000 \mathrm{sel} / \mathrm{mm}^{3}$ yaitu $76,9 \%$ dan berdasarkan derajat 1 sebagian besar kadar hematokrit normal yaitu 63,9\% dan pada derajat 2 sebagian besar kadar hematokrit normal yaitu $73,1 \%$. Kesimpulan: jumlah trombosit dengan rata-rata $87.790 \mathrm{sel} / \mathrm{mm}^{3}\left(<100.000 \mathrm{sel} / \mathrm{mm}^{3}\right)$, dan memiliki kadar hematokrit paling banyak dalam tingkatan normal.
\end{abstract}

Katakunci - Demam Berdarah Dengue, Hematokrit, Trombosit. 
39 Heme, Vol I No 1

January 2019

\begin{abstract}
Background: Dengue Hemorrhagic Fever (DHF) is a disease caused by the dengue virus. The West Sumatra Health Service reported that the city of Padang was the highest city in the incidence of dengue hemorrhagic fever in West Sumatra. Objective: It is known that platelet counts and hematocrit levels are important indicators in determining the occurrence of shock and the severity of the disease. Method: This type of research is a descriptive study using a cross sectional design with a retrospective approach, this study was conducted at the Siti Rahmah Islamic Hospital in Padang. The population in this study were all medical record data of patients who had been diagnosed with dengue hemorrhagic fever by a specialist in internal medicine at the Siti Rahmah Islamic Hospital in Padang period 1 January-31 December 2017, as many as 162 people with 62 samples using Simple random sampling technique. Result: Univariate analysis is presented in the form of a frequency distribution platelet counts $<100,000$ cells $/ \mathrm{mm}^{3}$ is $64.5 \%$ with an average platelet count of 87,790 cells $/ \mathrm{mm}^{3}$. Most of the normal hematocrit levels were $67.7 \%$ with an average hematocrit level of $40.45 \%$. Based on degree 1 most with platelet counts $<100,000$ cells $/ \mathrm{mm}^{3}$ which is $55.6 \%$, at degree 2 mostly with platelet counts $<100,000$ cells $/ \mathrm{mm}^{3}$ which is $76.9 \%$ and based on degree 1 most hematocrit levels are normal is $63.9 \%$ and at degree 2 most of the normal hematocrit levels are 73.1\%.Conclusion: the platelet count with a mean of 87,790 cells / mm3 (<100,000 cells / mm3), and had the highest levels of hematocrit at normal levels
\end{abstract}

Keywords-Dengue Hemorrhagic Fever, Hematocrit, Thrombocytes

Email : heme@unbrah.ac.id 


\section{Pendahuluan}

Demam Berdarah Dengue (DBD) adalah penyakit yang disebabkan oleh virus dengue yang tergolong Arthropod-Borne Virus, genus Flavivirus, dan family Flaviviridae. DBD ditularkan melalui gigitan nyamuk dari genus Aedes, terutama Aedes aegypti. Penyakit DBD dapat muncul sepanjang tahun dapat menyerang seluruh kelompok umur. Munculnya penyakit ini berkaitan dengan kondisi lingkungan dan perilaku masyarakat.1Penyakit demam berdarah dengue (DBD) pertama kali dilaporkan di Asia Tenggara pada tahun 1954 yaitu di Filipina, selanjutnya menyebar keberbagai negara. ${ }^{2}$

Sejak tahun 1968 hingga tahun 2009, World Health Organization (WHO) mencatat bahwa negara Indonesia sebagai negara dengan kasus DBD tertinggi di Asia Tenggara. Penyakit DBD di Indonesia pertama kali ditemukan di Surabaya pada tahun 1968 di mana sebanyak 58 orang terinfeksi dan 24 orang di antaranya meninggal dunia (Angka Kematian (AK): 41,3\%), dan sejak saat itu penyakit ini menyebar luas ke seluruh Indonesia. $^{3}$

Dinas Kesehatan Sumatra Barat melaporkan bahwa kotaPadang merupakan kota tertinggi angka kejadian demamberdarah dengue di Sumatra Barat, dilaporkan pada tahun2014 angka kejadian DBD yaitu 666 kasus dan meningkatpada tahun 2015 yaitu 830 kasus DBD. ${ }^{4}$ Tiga kecamatan dengan angka kejadian DBD tinggi pada tahun 2015 di Kota Padang adalah Kecamatan Koto Tangah dengan 222 kasus, Kecamatan Kuranji dengan 213 kasus, dan Kecamatan Padang Timur dengan 100 kasus. ${ }^{5}$

Penyakit DBD memiliki dua perubahan patologik utama, yakni peningkatan permeabilitas kapiler dan gangguan hemostasis. Pertama, terjadi peningkatan permeabilitas kapiler yang dapat menyebabkan kehilangan volume plasma pada pembuluh darah sehingga terjadi hemokonsentrasi. Peningkatan hematokrit sangat banyak ditemukan pada kasus syok sehingga pemeriksaan nilai hematokrit perlu dilakukan dalam pemantauan kasus penyakit DBD. ${ }^{6}$ Kedua, gangguan hemostasis yang disebabkan oleh vaskulopati, trombositopenia, dan juga koagulopati. Trombositopenia muncul pada hari ke-3 pada DBD, dan tetap bertahan selama perjalanan penyakit tersebut. Akibat dari gangguan hemostasis ini, maka terjadi manifestasi klinis perdarahan. Dewi et al. meneliti bahwa nilai jumlah trombosit dapat dipergunakan sebagai faktor untuk memprediksi kejadian syok. $^{6}$

Data insidensi DBD di RSI Siti Rahmah Padang pada tahun 2017 sebanyak 162 kasus. Berdasarkan tingginya insidensi dan kematian akibat DBD di Kota Padang, terutama di kecamatan koto tangah pada tahun 2015 yaitu sebanyak 222 kasus dan diketahui bahwa jumlah trombosit serta kadar hematokrit merupakan indikator penting dalam menentukan terjadinya syok, maka penulis tertarik untuk mengetahui bagaimana gambaran jumlah trombosit dan kadar hematokrit dengan berbagai derajat klinis pada pasien DBD di RSI Siti Rahmah Padang.

\section{Metode Penelitian}

Jenis penelitian ini adalah penelitian deskriptif menggunakan rancangan cross sectional dengan pendekatan retrospektif untuk mengetahui gambaran jumlah trombosit dan kadar hematokrit pada pasien demam berdarah dengue (DBD) di Rumah Sakit Islam Siti Rahmah Padang Tahun 2017.

Populasi dalam penelitian ini adalah seluruh data rekam medik pasien yang sudah didiagnosis demam berdarah dengue oleh dokter Spesialis Penyakit Dalam periode 1 
Januari-31 Desember 2017, yaitu sebanyak 162 orang.Sampel penelitian ini dipilih menggunakan metode Probability sampling dengan teknik Simple random samplingdengan cara undian. Sampel dalam penelitian ini adalah rekam medik yang memenuhi kriteria inklusi dan kriteria eksklusi.Analisis data yang digunakan pada penelitian ini adalah analisis univariat.

\section{HASIL}

Penelitian ini bertujuan untuk melihat gambaran jumlah trombosit dan kadar hematokrit pada pasien DBD di RSI Siti Rahmah Padang tahun 2017 yang dilakukan pada 62 sampel penelitian yang telah memenuhi kriteria inklusi dan eksklusi. Dari penelitian yang dilakukan maka didapatkan hasil sebagai berikut:

TABEl 1 Distribusi FreKUENSI UMUR PADA PASIEN DBD DI RSI SITI RAHMAH PADANG TAHUN 2017

\begin{tabular}{lll}
\hline Umur & $\boldsymbol{n}$ & $\boldsymbol{\%}$ \\
\hline Dewasa awal (18-40 Tahun) & 43 & 69,4 \\
Dewasa madya (41-60 Tahun) & 15 & 24,2 \\
Dewasa lanjut (>60 Tahun) & 4 & 6,4 \\
\hline Jumlah & 62 & 100 \\
\hline
\end{tabular}

Berdasarkan tabel 5.1 dapat disimpulkan bahwa dari 62 sampel pasien DBD, umur terbanyak adalah dewasa awal yaitu sebanyak 43 orang $(69,4 \%)$.

TABEL 5.2 DistRIBUSI FREKUENSI JENIS KELAMIN PADA PASIEN DBD di RSI SITI RAHMAH PADANG TAHUN 2017

\begin{tabular}{lcc}
\hline \multicolumn{1}{c}{ JenisKelamin } & $\boldsymbol{n}$ & $\boldsymbol{\%}$ \\
\hline Laki-Laki & 26 & 41,9 \\
Perempuan & 36 & 58,1 \\
\hline Jumlah & 62 & 100 \\
\hline
\end{tabular}

Berdasarkan tabel 5.2 dapat disimpulkan bahwa dari 62 sampel pasien DBD, jenis kelamin terbanyak adalah perempuan yaitu sebanyak 36 orang $(58,1 \%)$.
TABEL 5.3 DistribUSI FREKUENSI DERAJAT KLINIS Pada Pasien DBD di RSI Siti Rahmah PADANG TAHUN 2017

\begin{tabular}{lll}
\hline Derajat Klinis & $\boldsymbol{n}$ & $\boldsymbol{\%}$ \\
\hline Derajat 1 & 36 & 58,1 \\
Derajat 2 & 26 & 41,9 \\
\hline Jumlah & 62 & 100 \\
\hline
\end{tabular}

Berdasarkan tabel 5.3 dapat disimpulkan bahwa dari 62 sampel pasien DBD, derajat klinis paling banyak adalah derajat 1 yaitu 36 orang $(58,1 \%)$. Kemudian ditemukan pasien derajat 2 yaitu 26 orang $(41,9 \%)$ dan tidak ditemukan pasien dengan derajat 3 maupun derajat 4.

TABEL 5.4 DisTRIBUSI FREKUENSI JUMLAH Trombosit Pada PASIEN DBD di RSI Siti RAHMAH PADANG TAHUN 2017

\begin{tabular}{|c|c|c|c|}
\hline $\begin{array}{l}\text { Jumlah } \\
\text { Trombosit }\end{array}$ & $n(\%)$ & Mean \pm SD & $\begin{array}{l}\text { Rentang } \\
\text { (Min- } \\
\text { Maks) } \\
\end{array}$ \\
\hline $\begin{array}{l}<100.000 \\
\mathrm{sel} / \mathrm{mm}^{3}\end{array}$ & $40(64,5)$ & $\begin{array}{l}87.790 \\
\pm 30.55\end{array}$ & $\begin{array}{l}20.000- \\
139.000\end{array}$ \\
\hline $\begin{array}{l}100.000- \\
150.000 \\
\mathrm{sel} / \mathrm{mm}^{3}\end{array}$ & $22(35,5)$ & & \\
\hline Jumlah & $62(100)$ & & \\
\hline
\end{tabular}

Berdasarkan tabel 5.4 dapat disimpulkan bahwa dari 62 sampel pasien DBD, jumlah trombosit paling banyak adalah $<100.000$ $\mathrm{sel} / \mathrm{mm} 3$ yaitu 40 orang $(64,5 \%)$ dengan ratarata jumlah trombosit adalah 87.790 $\mathrm{sel} / \mathrm{mm} 3$. 
TABEL 5.5 DISTRIBUSI FREKUENSI KADAR Hematokrit Pada PASIEN DBD di RSI SITI RAHMAH PADANG TAHUN 2017

\begin{tabular}{|c|c|c|c|}
\hline Kadar Hematokrit & $n(\%)$ & $\begin{array}{l}\text { Mean } \pm \\
\text { SD }\end{array}$ & $\begin{array}{l}\text { Rentang } \\
\text { (Min- } \\
\text { Maks) }\end{array}$ \\
\hline $\begin{array}{l}\text { Rendah } \\
\text { a.Laki-laki : }<40 \% \\
\text { b.Perempuan: }<37 \%\end{array}$ & $\begin{array}{l}15 \\
(24,2)\end{array}$ & $\begin{array}{l}40,45 \pm \\
4,48\end{array}$ & $30,5-52$ \\
\hline $\begin{array}{l}\text { Normal } \\
\text { a.Laki-laki : 40-48\% } \\
\text { b.Perempuan: } 37-43 \%\end{array}$ & $\begin{array}{l}42 \\
(67,7)\end{array}$ & & \\
\hline $\begin{array}{l}\text { Tinggi } \\
\text { a.Laki-laki : }>48 \% \\
\text { b.Perempuan: }>43 \%\end{array}$ & $5(8,1)$ & & \\
\hline Jumlah & $\begin{array}{l}62 \\
(100)\end{array}$ & & \\
\hline
\end{tabular}

Berdasarkan tabel 5.5 dapat disimpulkan bahwa dari 62 sampel pasien DBD, kadar hematokrit paling banyak adalah normal yaitu 42 orang $(67,7 \%)$ dengan rata-rata kadar hematokrit adalah 40,45

TABEL 5.6 DISTRIBUSI FREKUENSI JUMLAH Trombosit BERDASARKAN DERAJAT KLINIS PADA PASIEN DBD DI RSI SITI RAHMAH PADANG TAHUN 2017

\begin{tabular}{|c|c|c|c|c|c|c|}
\hline \multirow{3}{*}{$\begin{array}{l}\text { Jumlah } \\
\text { Trombosit }\end{array}$} & \multicolumn{4}{|c|}{ Derajat Klinis DBD } & \multicolumn{2}{|c|}{ Total } \\
\hline & \multicolumn{2}{|c|}{ Derajat 1} & \multicolumn{2}{|c|}{ Derajat 2} & & \\
\hline & $f$ & $\%$ & $f$ & $\%$ & $f$ & $\%$ \\
\hline $\begin{array}{l}<100.000 \\
\mathrm{sel} / \mathrm{mm}^{3}\end{array}$ & 20 & 55,6 & 20 & 76,9 & 40 & 64,5 \\
\hline $\begin{array}{l}100.000- \\
150.000 \\
\mathrm{sel} / \mathrm{mm}^{3}\end{array}$ & 16 & 44,4 & 6 & 23,1 & 22 & 35,5 \\
\hline Total & 36 & 100 & 26 & 100 & 62 & 100 \\
\hline
\end{tabular}

Berdasarkan tabel 5.6 dapat disimpulkan bahwa dari 62 sampel pasien DBD, jumlah trombosit berdasarkan derajat 1 sebagian besarjumlah trombosit $<100.000 \mathrm{sel} / \mathrm{mm}^{3}$ yaitu 20 orang $(55,6 \%)$, pada derajat 2 sebagian besar jumlah trombosit $<100.000 \mathrm{sel} / \mathrm{mm}^{3}$ yaitu 20 orang $(76,9 \%)$.
TABEL 5.7DISTRIBUSI FREKUENSI KADAR HEMATOKRIT BERDASARKAN DERAJAT KLINIS Pada Pasien DBD di RSI Siti RahMah Padang TAHUN 2017

\begin{tabular}{|c|c|c|c|c|c|c|}
\hline \multirow{3}{*}{$\begin{array}{l}\text { Kadar } \\
\text { Hematokrit }\end{array}$} & \multicolumn{4}{|c|}{ Derajat Klinis DBD } & \multicolumn{2}{|c|}{ Total } \\
\hline & \multicolumn{2}{|c|}{ Derajat 1} & \multicolumn{2}{|c|}{ Derajat 2} & \multirow[b]{2}{*}{$n$} & \multirow[b]{2}{*}{$\%$} \\
\hline & $n$ & $\%$ & $n$ & $\%$ & & \\
\hline $\begin{array}{l}\text { Rendah } \\
\text { a. Laki-laki : } \\
<40 \% \\
\text { b. Perempuan : } \\
<37 \%\end{array}$ & 10 & 27,8 & 5 & 19,2 & 15 & 24,2 \\
\hline $\begin{array}{l}\text { Normal } \\
\text { a. Laki-laki : } 40- \\
48 \% \\
\text { b. Perempuan : } \\
37-43 \%\end{array}$ & 23 & 63,9 & 19 & 73,1 & 42 & 67,7 \\
\hline $\begin{array}{l}\text { Tinggi } \\
\text { a. Laki-laki : } \\
>48 \% \\
\text { b. Perempuan : } \\
>43 \%\end{array}$ & 3 & 8,3 & 2 & 7,7 & 5 & 8,1 \\
\hline Total & 36 & 100 & 26 & 100 & 62 & 100 \\
\hline
\end{tabular}

Berdasarkan tabel 5.7 dapat disimpulkan bahwa dari 62 sampel pasien DBD, kadar hematokrit berdasarkan derajat 1 sebagian besar dengan kadar hematokrit normal yaitu 23 orang $(63,9 \%)$ dan pada derajat 2 sebagian besar dengan kadar hematokrit normal yaitu 19 orang $(73,1 \%)$.

\section{Pembahasan}

\section{A. Karakteristik Dasar Subyek Penelitian}

Berdasarkan penelitian dari 62 sampel pasien DBD, umur terbanyak adalah dewasa awal (18-40 tahun) yaitu sebanyak 43 orang $(69,4 \%)$ pada pasien DBD di RSI Siti Rahmah Padang tahun 2017. Sejalan dengan penelitian yang dilakukan oleh Hidayta, (2017) diperoleh hasil paling banyak umur pasien adalah 20-40 tahun yaitu (50\%) dan penelitian Valentino pada tahun 2012 bahwa berdasarkan umur, penderita DBD terbanyak adalah pada umur 19 tahun. $^{7}$ Umur adalah salah satu faktor yang mempengaruhi kepekaan terhadap infeksi virus dengue. Penelitian di Kuba pada tahun 1981 yang dikutip oleh Sutaryo didapatkan bahwa umur mempunyai peranan yang penting untuk 
timbulnya gejala klinis berupa kebocoran plasma. $^{7}$

Jenis kelamin terbanyak adalah perempuan yaitu sebanyak 36 orang $(58,1 \%)$ pada pasien DBD di RSI Siti Rahmah Padang tahun 2017. Berdasarkan jenis kelamin, sejalan dengan Hukom, (2013) diperoleh hasil paling banyak pasien DBD adalah perempuan $(53,2 \%){ }^{6}$ Penelitian terdahulu dilakukan Hidayta, (2017) didapatkan hasil yang berbeda, bahwa jenis kelamin laki-laki lebih banyak, yaitu berjumlah 81 orang $(58,7 \%)$, sedangkan perempuan berjumlah $57 \quad(41,3 \%){ }^{7} \quad$ Perempuan dan laki-laki memiliki potensi yang sama untuk terkena gigitan nyamuk Aedes aegypti. ${ }^{8}$

Derajat klinis paling banyak adalah pada derajat 1 yaitu 36 orang $(58,1 \%)$ pada pasien DBD di RSI Siti Rahmah Padang tahun 2017. Sejalan dengan penelitian Santhi, (2016) diperoleh hasil paling banyak derajat 1 yaitu (49,3\%) dan penelitian yang dilakukan oleh Sisjufri, (2016) diperoleh hasil $(42 \%)$ pasien dengan derajat $1 .{ }^{9}$ Banyaknya pasien berada pada derajat 1 , hal ini disebabkan karena perawatan yang cepat sehingga DBD bisa dicegah ke derajat selanjutnya. ${ }^{9}$

Jumlah trombosit paling banyak adalah $<100.000 \mathrm{sel} / \mathrm{mm}^{3}$ yaitu 40 orang $(64,5 \%)$ dengan rata-rata jumah trombosit adalah $87.790 \mathrm{sel} / \mathrm{mm}^{3}$ pada pasien DBD di RSI Siti Rahmah Padang tahun 2017. Hal ini didukung oleh penelitian Nopianto pada tahun 2012 yang menyatakan bahwa terdapat $77 \%$ pasien DBD yang memiliki jumlah trombosit $<100.000 \mathrm{sel} / \mathrm{mm}^{3}{ }^{7}$ Noisakran et al, (2008) menemukan bahwa destruksi trombosit tidak hanya disebabkan oleh virus dengue itu sendiri, tetapi juga oleh pertemuan antibodi dengan trombosit yang telah terinfeksi virus dengue. ${ }^{6}$

Kadar hematokrit paling banyak adalah normal yaitu 42 orang $(67,7 \%)$ dan 5 orang
$(8,1 \%)$ dengan kadar diatas normal atau tinggi dengan rata-rata kadar hematokrit adalah 40,45\% pada pasien DBD di RSI Siti Rahmah Padang tahun 2017. Penelitian yang dilakukan oleh Pratiwi pada tahun 2011 didapatkan hal yang sama, yaitu dalam penelitiannya hanya $22 \%$ yang memiliki kadar hematokrit di atas normal. Penelitian oleh Taufik et al pada tahun 2007 menyatakan bahwa hanya $16 \%$ penderita DBD yang mengalami peningkatan nilai hematokrit. ${ }^{7}$ Peningkatan nilai hematokrit menggambarkan kondisi hemokonsentrasi yang selalu dijumpai pada pasien DBD, dan merupakan indikator yang peka akan terjadinya kebocoran plasma, sehingga perlu dilakukan pemeriksaan hematokrit secara berkala. ${ }^{10}$ Nilai hematokrit akan menurun saat terjadinya hemodilusi, karena penurunan kadar seluler darah atau peningkatan kadar plasma darah, seperti pada anemia. ${ }^{7}$

Jumlah trombosit berdasarkan derajat 1 paling banyak dengan jumlah trombosit $<100.000 \mathrm{sel} / \mathrm{mm}^{3}$ yaitu 20 orang $(55,6 \%)$, pada derajat 2 paling banyak dengan jumlah trombosit $<100.000 \mathrm{sel} / \mathrm{mm}^{3}$ yaitu 20 orang (76,9\%) pada pasien DBD di RSI Siti Rahmah Padang tahun 2017. Dari hasil penelitian di atas maka dapat disimpulkan bahwa semakin rendah jumlah trombosit seseorang maka semakin berat derajat DBD. Sejalan dengan penelitian yang dilakukan oleh Almira, (2015) bahwa dari total 42 sampel, 33 diantaranya memiliki jumlah trombosit yang $<100.000 \mathrm{sel} / \mathrm{mm}^{3}$ dengan presentase $78,6 \%$ yang sebagian besar dijumpai pada pasien DBD grade II. ${ }^{11}$ Pada pasien demam berdarah selain jumlah trombosit yang menurun, fungsi trombosit juga menurun. Oleh karena itu biasanya disebutkan bahwa pada pasien DBD trombosit terganggu baik secara kuantitas maupun secara kualitas. ${ }^{12}$

Kadar hematokrit berdasarkan derajat 1 paling banyak dengan kadar hematokrit normal yaitu 23 orang $(63,9 \%)$, pada derajat 
2 paling banyak dengan kadar hematokrit normal yaitu 19 orang $(73,1 \%)$, sedangkan pada derajat 1 yang mengalami peningkatan nilai hematokrit sebanyak 3 orang $(8,3 \%)$ dan pada derajat 2 sebanyak 2 orang $(7,7 \%)$ pada pasien DBD di RSI Siti Rahmah Padang tahun 2017. Penelitian sebelumnya yang dilakukan oleh Ikrima,dkk (2017) juga menunjukkan bahwa sebagian besar responden dengan kadar hematokrit normal sebanyak 39 orang dengan persentase $63,9 \%$ dan derajat klinis terbanyak yaitu derajat II dengan persentase $39,3 \%$. sejalan dengan penelitian Rasyada (2014) bahwa nilai hematokrit pada pasien DBD normal bahkan rendah dan didiagnosis DBD. ${ }^{13}$ Nilai hematokrit adalah besarnya volume sel eritrosit di dalam $100 \mathrm{~mm}^{3}$ darah dan dinyatakan dalam persen. Pada kasus DBD, terjadinya peningkatan nilai hematocrit (hemokonsentrasi) dikarenakan oleh penurunan kadar plasma darah akibat kebocoran vaskuler. Nilai hematokrit akan menurun saat terjadinya hemodilusi, karena penurunan kadar seluler darah atau peningkatan kadar plasma darah, seperti pada anemia. ${ }^{7}$

\section{Kesimpulan Dan SARan}

Berdasarkan gambaran jumlah trombosit dan kadar hematokrit pada pasien DBD di RSI Siti Rahmah Padang tahun 2017, maka dapat disimpulkan bahwa ditemukan jumlah trombosit dengan rata-rata 87.790 $\mathrm{sel} / \mathrm{mm}^{3}\left(<100.000 \mathrm{sel} / \mathrm{mm}^{3}\right)$, dan memiliki kadar hematokrit paling banyak dalam tingkatan normal.

\section{Daftar Pustaka}

[1] Kementerian Kesehatan RI. Infodatin Situasi DBD di Indonesia. Jakarta: Pusdatin Kementrian Kesehatan RI. (2016).

[2] WHO. Dengue and Severe Dengue. (2014).

[3] Zumaroh. Evaluasi pelaksanaan surveilans kasus demam berdarah dengue di puskesmas putat jaya berdasarkan atribut surveilans. p:82-94 (2013).

[4] Dinas Kesehatan Provinsi Sumatera Barat. Profil Kesehatan Provinsi Sumatera Barat. Padang:
Dinas Kesehatan Provinsi Sumatera Barat. (2015).

[5] Dinas Kesehatan Kota Padang. Profil Kesehatan Kota Padang Tahun 2014. Available from: https:// dinkeskotapadang1.files.wordpress.com /2015/ 07/ profil-tahun-2014-edisi-2015.pdf ( Diakses Pada Tanggal 02 Agustus 2018). (2015).

[6] Hukom, A. O. E. \& Warouw, S. M. Hubungan Nilai Hematokrit dan Nilai Jumlah Trombosit Pada Pasien Demam Berdarah Dengue. 133, 707711 (2013).

[7] Wardhy Arief Hidayat, Rismawati Yaswir, A. W. M. Hubungan Jumlah Trombosit dengan Nilai Hematokrit pada Penderita Demam Berdarah Dengue dengan Manifestasi Perdarahan Spontan di RSUP Dr. M. Djamil Padang. 6, 2 (2017).

[8] Rizza Umaya, Ahmad Fickry Faisya, E. S. Hubungan Karakteristik Pejamu, Lingkungan Fisik dan Pelayanan Kesehatan dengan Kejadian Demam Berdarah Dengue (DBD) di Wilayah Kerja Puskesmas Talang Ubi Pendopo Tahun 2012. 4, 262-269 (2013).

[9] Yobi Syumarta, Akmal M.Hanif, E. R. Hubungan Jumlah Trombosit, Hematokrit dan Hemoglobin dengan Derajat Klinik Demam Berdarah Dengue pada Pasien Dewasa di RSUP . M.Djamil Padang. 38, 492-498 (2013).

[10]Dgd. Dharma Santhi. Derajat Klinis Demam Berdarah Dengue Berdasarkan Kriteria WHO 2011. Denpasar: Fakuktas Kedokteran Universitas Udayana.(2011).

[11] Cristina E. Heatubun, Adrian Umboh, Arthur E. Mongan, F. M. Perbandingan Jumlah Trombosit Pada Demam Berdarah Dengue Tanpa Syok dan Syok di RSUP Prof.Dr.R.D. Kandou Manado. 1,Manado : Universitas Sam Ratulangi.(2013).

[12]Nurjannah. Faktor-faktor yang berhubungan dengan derajat demam berdarah dengue dbd di kota makassar. Makassar: Fakultas Ilmu Kesehatan UIN Alauddin Makassar. (2010).

[13] Suhendro, Leonard Nainggolan, Khie Chen, H. Demam Berdarah Dengue. Dalam: Buku Ajar Ilmu Penyakit Dalam. Jilid I. Jakarta: Interna Publishing.(2014). 